\title{
Mechanistic rationales for targeting interleukin-17A in spondyloarthritis
}

Siba P. Raychaudhuri ${ }^{1,2^{*}}$ and Smriti K. Raychaudhuri ${ }^{1}$

\begin{abstract}
The term spondyloarthritis (SpA) is used to describe a group of inflammatory autoimmune diseases, including ankylosing spondylitis and psoriatic arthritis, with common genetic risk factors and clinical features. SpA is clinically distinct from rheumatoid arthritis and typically affects the spine, sacroiliac joints, entheses, and, less commonly, peripheral joints. Although the pathogenesis of SpA is not fully understood, recent findings have identified the interleukin (IL)-17 pathway as a key mediator of disease pathogenesis. Clinical evidence for the efficacy of IL-17A inhibition by biologic agents was initially shown in patients with chronic plaque psoriasis, another autoimmune disease mediated by the IL-17 pathway. Subsequently, similar positive efficacy for inhibition of IL-17A was seen in patients with ankylosing spondylitis and psoriatic arthritis. Inhibition of IL-17A may also improve cardiovascular and metabolic comorbidities often found in patients with SpA because studies have linked these disorders to the IL-17 pathway. In this review, we will examine key preclinical studies that demonstrated the mechanistic role of IL-17A in the development SpA and discuss how these observations were translated into clinical practice.
\end{abstract}

Keywords: Spondyloarthritis, Review, Interleukin-17, IL-17A inhibition, Ankylosing spondylitis, Psoriatic arthritis, Preclinical studies, Clinical practice

\section{Background}

Spondyloarthritis (SpA) is a term used to describe a group of inflammatory autoimmune diseases that share common genetic risk factors and clinical features, including ankylosing spondylitis (AS), psoriatic arthritis (PsA), reactive arthritis, undifferentiated SpA, and enteropathic arthritis [1-6]. SpA typically affects the spine, sacroiliac joints, entheses, and peripheral joints. Hallmark features of SpA include enthesitis, focal inflammation, new bone formation and cartilage ossification that may lead to ankyloses [2, 4, 7-9]. Clinical phenotypes include inflammatory back pain, oligoarthritis, dactylitis, and extra-articular features such as uveitis, psoriasis, and inflammatory bowel disease (IBD) [5].

Worldwide estimates of the prevalence of SpA are variable. Available data suggest that $\mathrm{SpA}$ is relatively uncommon in Asian and Middle Eastern countries,

\footnotetext{
* Correspondence: sraychaudhuri@ucdavis.edu

'VA Medical Center Sacramento, Division of Rheumatology \& Immunology, Sacramento, CA, USA

2Division of Rheumatology, Allergy \& Clinical immunology, University of California School of Medicine, Davis, \& VA Medical Center Sacramento, Sacramento, CA, USA
}

affecting less than $0.9 \%$ of adult populations, while studies in European countries report SpA prevalence of between $0.3 \%$ and $1.9 \%$ [5]. According to data from the 2009-2010 US National Health and Nutrition Examination Survey (NHANES), it is estimated that SpA affects roughly $1 \%$ of the adult population in the US, which corresponds to between two million and three million people [6].

The exact pathogenesis of SpA is not well understood, but in recent years it has become clear that cytokines associated with innate and adaptive inflammatory immune responses play an important role in disease initiation and progression [2, 8, 9]. Cytokines produced by $\mathrm{T}$ helper (Th)17 cells have been shown to contribute to pathogenic features of SpA, including joint erosion and inflammation, new bone formation, epidermal thickening, development of psoriatic skin lesions, pannus formation in joint capsules, synovial inflammation, and angiogenesis [7-12]. Specifically, preclinical studies using models of SpA have shown that expression of genes encoding proinflammatory cytokines including interleukin (IL)-17A, tumor necrosis factor (TNF)- $\alpha$, and IL-23 is upregulated in affected joints $[9,13]$ and that IL-17 promotes 
osteogenesis at inflamed sites (e.g., entheses) under conditions of mechanical stress, resulting in excess bone formation that is a key characteristic difference between SpA and rheumatoid arthritis (RA), which is characterized predominantly by bone erosion and resorption [14]. As such, the IL-17 pathway has been identified as a potential disease-modifying target for the treatment of SpA [9, 12, 15]. This article provides a review of the pathogenesis of SpA and the mechanistic rationales for targeting the IL17A pathway based on its role in inflammation, cartilage damage, and bone changes.

\section{Methods}

Literature searches were conducted using PubMed to identify relevant articles and these results were supplemented by reference checking and with the authors' familiarity of the literature. Due to the large number of articles discussing IL-17A in SpA, a narrative review was deemed to be most appropriate for this manuscript.

\section{IL-17A in the pathogenesis of SpA}

IL-17 signaling has been identified as a key modulator of synovial inflammation and joint destruction in various arthropathies through its actions on synovial cells, osteoblasts, and chondrocytes (Fig. 1) [12]. Of the six members of the IL-17 cytokine family, IL-17A is the most well characterized, existing as a homodimer or as part of a heterodimer with IL-17F $[8,15]$. Cellular production of IL-17 is complex and heterogeneous. Table 1 provides an overview of the diverse cellular sources of this cytokine. Notably, IL-
17A and IL-17F are primarily produced by naive $\mathrm{CD}^{+}{ }^{+} \mathrm{T}$ cells that differentiate into Th17 cells in response to stimulation by IL-23 $[8,16]$. In addition, IL-17A is produced by $\mathrm{CD} 8^{+} \mathrm{T}$ cells, $\gamma \delta \mathrm{T}$ cells, natural killer cells, mast cells, neutrophils, and group 3 innate lymphoid cells [8]. Binding of IL-17A homodimers to the heterodimeric transmembrane IL-17 receptor (IL-17RA and IL-17RC) is a potent signal driving autoimmune inflammatory responses associated with arthritis-related tissue damage and joint destruction, as well as with mucocutaneous defense mechanisms against extracellular pathogens $[8,12,14,17,18]$. Furthermore, Th17 cells ( IL-17A/IL-22) and its receptor system play important roles in osteoclast-mediated bone changes and cartilage destruction associated with inflammatory arthritis [2, $9,14]$. The IL-17 receptor is expressed by osteoclasts, osteoblasts, synoviocytes, and chondrocytes, and stimulation of IL-17A triggers Th17 cells, osteoblasts, and synovial fibroblasts to produce the receptor activator of nuclear factor$\mathrm{\kappa B}$ ligand (RANKL), which plays a vital role in production of osteoclasts and osteoclastic precursors [14].

Many basic research studies using in vitro and animal models have helped elucidate the roles of IL-17A and related cytokines in arthritis pathogenesis. Early mouse models of collagen-induced arthritis (CIA) identified IL17 as a key contributor to RANKL-induced bone erosion and inflammatory joint destruction [19, 20]. Subsequently, tissue microscopy studies have shown that $\mathrm{T}$ cells with high levels of IL-23 receptors are present at the entheseal interface between tendon and bone of both axial and peripheral articular locations [9]. When IL-23

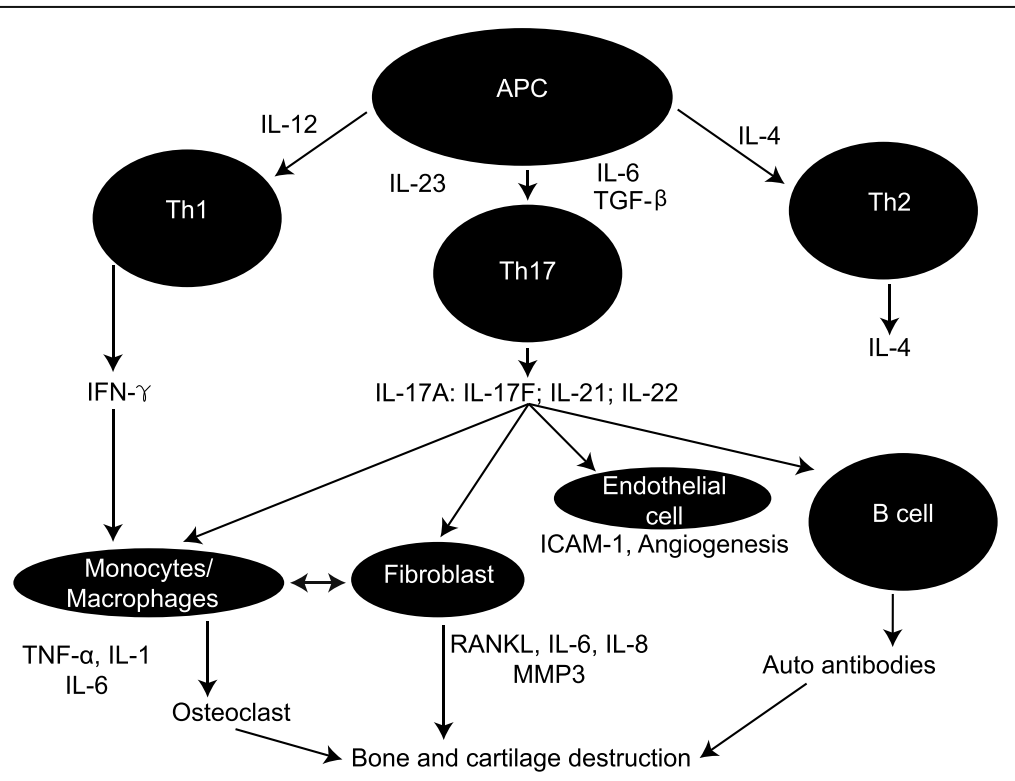

Fig. 1 Pathogenic role of IL-17A in SpA [12]. Reprinted from Raychaudhuri SP. Role of IL-17 in psoriasis and psoriatic arthritis. Clin Rev Allergy Immunol. 2013;44:183-93, with permission of Springer. APC antigen-presenting cell, ICAM-1 intercellular adhesion molecule-1, IL interleukin, IFN interferon, MMP3 matrix metalloproteinase 3, TGF transforming growth factor, RANKL receptor activator of nuclear factor-kB ligand, Th T-helper, TNF tumor necrosis factor 
Table 1 Types of IL-17-producing cells $[8,12,33,36,38,76-80]$

\begin{tabular}{|c|c|}
\hline Cell type & Description \\
\hline Adaptive Th17 cells & $\begin{array}{l}\text { - A subset of activated } C D 4^{+} T \text { helper cells that produce high levels } \\
\text { of } I L-17 A, I L-17 F \text {, and IL-22, and express IL-23R } \\
\text { - } C D 4^{+} T C R a / \beta^{+} \text {Th17 cells are a well characterized source of } I L-17 \text { that play a key } \\
\text { role in immune inflammatory responses }\end{array}$ \\
\hline Natural Th17 cells & $\begin{array}{l}\text { - Subset of thymic Th17 cells that acquire effector function prior } \\
\text { to peripheral antigen exposure } \\
\text { - These cells have different TCR gene usage and signaling properties } \\
\text { compared with conventional Th17 cells }\end{array}$ \\
\hline$\gamma / \delta T$ cells & $\begin{array}{l}\text { - Potent source of innate IL-17 produced independently of IL-6 } \\
\text { - Properties are similar to Th17 cells (e.g., expression of CCR6, IL-23R, and RORyt); } \\
\text { these cells also express TLR1, TLR2, and Dectin-1 } \\
\text { - Levels of IL-17-producing } \gamma / \delta T \text { cells increase during some types of bacterial infections } \\
\text { - Different subsets of } \gamma / \delta T \text { cells in the thymus produce either IL-17 or IFNy } \\
\text { - Major source of gut-protective IL-17, which acts independently from IL-23 }\end{array}$ \\
\hline iNKT cells & $\begin{array}{l}\text { - Cells that express a restricted TCR that recognizes glycolipid antigens } \\
\text { - May provide an alternative source of IL-17 when IL-6 is not present to stimulate Th17 cells } \\
\text { - IL-17 } 7^{+} \text {cells express IL-23R and IL-1R1 }\end{array}$ \\
\hline Tc17 cells & $\begin{array}{l}\text { - Subset of } \mathrm{CD}^{+} \text {cells that produces } \mathrm{IL}-17 \\
\text { - May play a role in pathogenic skin and joint inflammation in psoriasis and PSA, respectively }\end{array}$ \\
\hline ILC3s & $\begin{array}{l}\text { - Subset of ILCs defined by their capacity to produce IL-17A and/or IL-22 } \\
\text { - The role of ILCs in SpA and other forms of destructive arthritis is unclear } \\
\text { because cell numbers are generally low }\end{array}$ \\
\hline Neutrophils & $\begin{array}{l}\text { - Source of IL-17 in effector phase of arthritis } \\
\text { - Myeloperoxidase }{ }^{+} \text {and } C D 15^{+} \text {neutrophils have been identified as sources } \\
\text { of IL-17 in facet joints of patients with SpA }\end{array}$ \\
\hline Mast cells & $\begin{array}{l}\text { - Primary source of } \mathrm{IL}-17^{+} \text {cells in synovial fluid of patients with SpA as } \\
\text { a result of innate immune responses }\end{array}$ \\
\hline
\end{tabular}

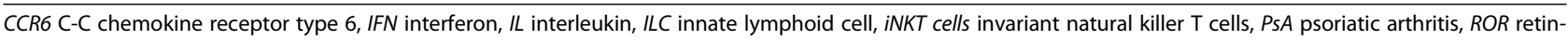
oic orphan receptor, SpA spondyloarthritis, TCR T-cell receptor, Th T-helper, TLR Toll-like receptor

levels were increased in cell cultures of these entheses, expression of IL-17A, IL-22, and bone morphogenic protein 7 increased, and IL-23 also induced severe enthesitis in animal models [9]. Initially, findings from genomic studies indicated that IL-23 receptor signaling plays a key role in the development of SpA, psoriasis, and IBD [21-24]. However, more recent studies in $\mathrm{IL}-17 \mathrm{~A}^{-/-}$ knockout mice have clarified that IL-23-mediated stimulation of IL-17A and IL-22 drives the development and severity of enthesitis [21]. Further substantiating the role of IL-17A in IL-23-induced local inflammation, Reinhardt and colleagues showed that entheseal $\gamma / \delta$ cell production is increased under conditions of inflammation and mechanical stress, stimulating production of IL-17A at anatomic sites commonly affected in SpA (e.g., Achilles tendon insertion, aortic root, and ciliary body) [25].

Further supporting the role of IL-17A signaling in the formation of pathogenic bone erosions, joint inflammation, and cartilage destruction, Lubberts and colleagues [26] observed that, in a mouse model of CIA, neutralization of endogenous IL-17A was associated with a decrease in systemic IL-6 and a reduction in cells that tested positive for RANKL and the inflammatory cytokine IL- $1 \beta$. In addition, Adamopoulos and colleagues [27] observed that IL-17A gene transfer in a mouse model of CIA induced the expansion of osteoclast precursors and increased serum levels of biomarkers associated with bone resorption, including tartrate-resistant acid phosphatase $5 \mathrm{~b}$ and carboxyterminal collagen crosslinks.

Findings consistent with the results from basic research studies have been observed in several different human studies in SpA. These studies have shown that levels of IL-17A, IL-23, IL-6, IL-1 $\beta$, IL-21, transforming growth factor (TGF)- $\beta$, TNF- $\alpha$, and interferon (IFN) $\gamma$ are increased in sera and synovial fluid of patients with reactive arthritis, AS, and undifferentiated SpA, and that Th17 cell levels are increased in peripheral blood samples from patients with PsA and AS [3, 28-31]. Pathologic Th17-cell overexpression of IL-17 has also been observed in the gut of patients with PsA, contributing to chronic subclinical inflammation [32].

A study from our group that highlights the role of IL17A signaling in inflammatory arthritis showed that elevated levels of IL-17A and IL-17RA are present in synovial tissue samples from patients with PsA and, when cultures of these tissue samples were treated with an anti-IL-17RA antibody, IL-17A-induced expression of IL-8, IL-6, and matrix metalloproteinase (MMP) 3 was decreased [33]. Another important study by Jansen and colleagues [34] showed that elevated levels of IL-17-producing CD4 $4^{+} \mathrm{T}$ cells are present in patients with early, active axial SpA 
Table 2 Differences between RA and SpA $[8,37]$

\begin{tabular}{|c|c|}
\hline$\overline{R A}$ & $\mathrm{SpA}$ \\
\hline $\begin{array}{l}\text { - Characterized primarily by symmetric polyarthritis and } \\
\text { inflammation resulting in cartilage and bone destruction }\end{array}$ & - Oligo/polyarthritis is more often asymmetrical \\
\hline - Axial involvement is rare & - Characterized primarily by axial disease of the sacroiliac joints and spine \\
\hline - More common in women than men & - More common in men than women \\
\hline - ACPA and RF antibodies are common & - ACPA and RF antibodies are absent \\
\hline - Strong genetic association with HLA-DR & - Most common genetic involvement is HLA-B27 \\
\hline - Central clinical feature is synovitis & $\begin{array}{l}\text { - Affects the axial skeleton and peripheral joints with synovial involvement, } \\
\text { especially in entheses, bone, and bone marrow (osteitis) }\end{array}$ \\
\hline - Driven by B- and/or T-cell autoreactivity & - Driven by innate immune cells (e.g., macrophages, PMN cells, mast cells) \\
\hline $\begin{array}{l}\text { - Macrophage effectors of synovial inflammation are driven } \\
\text { predominantly by IFNY }\end{array}$ & - Macrophage effectors of inflammation are driven predominantly by IL-17 \\
\hline - More pronounced hyperplasia of the synovial lining versus SpA & - Increased vascularity versus RA \\
\hline $\begin{array}{l}\text { - Extra-articular features include rheumatoid nodules, vasculitis, } \\
\text { pneumonitis, scleritis }\end{array}$ & - Extra-articular features include IBD, psoriasis, uveitis, aortitis \\
\hline - Little or no signs of tissue repair with joint damage & $\begin{array}{l}\text { - Joint damage is characterized by new cartilage and bone formation } \\
\text { (remodeling) }\end{array}$ \\
\hline
\end{tabular}

ACPA anti-citrullinated protein antibody, HLA human leukocyte antigen, IBD inflammatory bowel disease, IFN interferon, IL interleukin, $P M N$ polymorphonuclear, RA rheumatoid arthritis, $R F$ rheumatoid factor, SpA spondyloarthritis

with and without magnetic resonance imaging (MRI) abnormalities. Furthermore, Kenna and colleagues [35] observed that patients with active AS have increased levels of circulating $\gamma \delta \mathrm{T}$ cells that express IL-23R and produce IL-17, and a study by Noordenbos and colleagues [36] showed that synovial tissue from patients with SpA has increased levels of IL-17-expressing mast cells compared with tissue from patients with RA. Interestingly, this increase in IL-17 was not modulated by TNF- $\alpha$ blockade [36]. These studies highlight just a few key examples of the extensive research findings that have established IL17A signaling as an important pathway in the development and progression of SpA.

\section{Different roles of IL-17A in SpA and RA}

While there are many similarities between the chronic spinal and joint inflammation observed in patients with RA and SpA, it is important to note that these diseases have several unique clinical, radiologic, serologic, and genetic features driven by different underlying pathogenic signaling pathways (Table 2) [8, 37]. Moreover, while many of the same cytokines are present in both RA and SpA, differential expression levels result in substantial differences in characteristic bone changes. In RA, TNF- $\alpha$ is the predominant proinflammatory cytokine, promoting RANKL-driven osteoclast erosion, as well as suppression of osteoblast formation [14]. In contrast, the IL-17A pathway plays a predominant role in the promotion of osteoclastogenesis in patients with $\mathrm{SpA}$, and levels of circulating Th17 cells observed in the peripheral blood are much higher and more consistently observed than in patients with RA. Additionally, Th17 cells isolated from patients with SpA are more differentiated and polyfunctional than those from patients with RA [28]. These findings may be a result of different $\mathrm{T}$-cell lineages in RA and SpA. For example, Menon and colleagues [38] observed that IL-17 in patients with PsA was predominantly produced by $\mathrm{CD} 8^{+}$-derived $\mathrm{T}$ cells (Tc17 cells), while IL-17A-producing T cells were only produced from the $\mathrm{CD}^{+}$lineage in patients with $\mathrm{RA}$. Furthermore, these authors observed that the frequency of synovial fluid IL- $17^{+} \mathrm{CD} 4^{-} \mathrm{T}$ cells but not of IL $-17^{+} \mathrm{CD} 4^{+} \mathrm{T}$ cells was associated with clinical measures of PsA disease activity [38].

\section{Translation of IL-17 inhibition into clinical practice}

There is currently an unmet need in the treatment of SpA [39]. Traditional disease-modifying antirheumatic drugs (e.g., methotrexate) are ineffective in spinal inflammatory arthritis and AS. While the TNF- $\alpha$ inhibitors etanercept, adalimumab, infliximab, certolizumab pegol, and golimumab have all demonstrated efficacy in AS and PsA, a substantial proportion of patients either do not respond at all or respond inadequately, while some patients are unable to tolerate these drugs $[15,39-41]$. In recent years, other therapies used to treat RA have been investigated in AS, including the IL-1 receptor antagonist anakinra, the IL-6 inhibitor tocilizumab, the anti-CD20 antibody rituximab, and the costimulatory pathway inhibitor abatacept. However, none of these agents have demonstrated a meaningful clinical benefit in patients with AS [41].

It has been recognized that biologic agents with mechanisms of action other than TNF inhibition, which acts upstream of newer agents, would provide valuable 
alternatives for the treatment of SpA. However, until very recently there was a lack of alternatives to TNF- $\alpha$ inhibitors [39]. That changed with the approval of the IL-12/IL-23 antagonist ustekinumab, the phosphodiesterase 4 inhibitor apremilast, and the IL-17A inhibitor secukinumab for the treatment of PsA, and with the approval of secukinumab for the treatment of AS. Now, when patients fail to respond to one biologic due to lack of efficacy or poor tolerability, switching to another biologic with a different mechanism of action can be an effective treatment strategy $[42,43]$.

When choosing a biologic agent in $\mathrm{SpA}$, it is reasonable to consider preclinical findings that support the mechanistic rationale for targeting IL-17A. IL-17A seems to be a more downstream effector of SpA pathogenesis than other cytokines (i.e., IL-23, TGF- $\beta$, IL-6, and IL-1 $\beta$ ), which act upstream to trigger differentiation of Th17 cells in entheses and synovial tissue. Once activated, these Th17 cells stimulate production of downstream effector cytokines including IL-17 and IL-22, which contribute to inflammation, bone erosion, and bone fusion $[2,7,9,12,27,28,33]$. In addition to the good efficacy observed in SpA with this strategy, such downstream targeting may also be beneficial for patients with refractory SpA and those who are otherwise intolerant to other biologic therapies.

As clinical development programs for IL-17A inhibitors have progressed, findings from large-scale randomized controlled trials have supported the translation of IL-17A inhibition in SpA from bench to bedside. Positive findings have been observed in clinical studies of IL-17A inhibitors in psoriasis, PsA, and AS [44-49].

\section{Psoriasis}

The IL-17A inhibitor secukinumab is approved for the treatment of moderate-to-severe plaque psoriasis. In phase 3 clinical studies, secukinumab consistently provided substantial meaningful improvements in the signs and symptoms of moderate-to-severe chronic plaque psoriasis $[44,49]$. In the pivotal ERASURE and FIXTURE studies, more than half of patients who received secukinumab $300 \mathrm{mg}$ experienced a $90 \% \mathrm{im}-$ provement in Psoriasis Area and Severity Index (PASI90) scores at week 12, compared with $1 \%$ with placebo (ERASURE) and 21\% with etanercept (FIXTURE) [44]. In the CLEAR phase 3 study, secukinumab $300 \mathrm{mg}$ demonstrated superiority compared with ustekinumab for the primary endpoint of PASI90 at week $16(79.0 \%$ vs $57.6 \%$ response rates, respectively; $p<0.0001)$ [49].

The IL-17A inhibitor ixekizumab was recently approved for the treatment of moderate-to-severe plaque psoriasis. In the UNCOVER-2 and UNCOVER-3 randomized controlled phase 3 studies, up to $71 \%$ of patients treated with ixekizumab achieved PASI90 at week 12 , compared with $0.6 \%$ to $3.1 \%$ with placebo, and $18.7 \%$ to $25.7 \%$ with etanercept [45].

The anti-IL-17RA monoclonal antibody brodalumab was in late-stage development for the treatment of moderate-to-severe plaque psoriasis. Results of the phase 3 AMAGINE-1 study showed that, at week 12, PASI90 was achieved by $43 \%$ of patients treated with brodalumab $140 \mathrm{mg}$ and by $70 \%$ of patients treated with brodalumab $210 \mathrm{mg}$, compared with $1 \%$ of patients in the placebo group [50]. In the AMAGINE-2 and AMAGINE- 3 studies, brodalumab $210 \mathrm{mg}$ demonstrated higher efficacy compared with ustekinumab based on week 12 PASI90 responses (70\% vs $47 \%$ in AMAGINE-2, and $69 \%$ vs $48 \%$ in AMAGINE-3) [51]. However, the future of brodalumab development is uncertain based on observed events of suicidal ideation and behavior during clinical development [52].

\section{Psoriatic arthritis}

In early 2016, secukinumab received US Food and Drug Administration (FDA) approval for the treatment of active PsA. In the large-scale FUTURE 1 and FUTURE 2 phase 3 studies, patients received placebo or intravenous (IV) or subcutaneous (SC) induction dosing of secukinumab followed by SC maintenance dosing $[46,48]$. At week 24 in FUTURE 1, at least 20\% improvement in American College of Rheumatology response criteria (ACR20) responses were observed in $50 \%$ of patients receiving secukinumab $150 \mathrm{mg}, 51 \%$ receiving secukinumab $75 \mathrm{mg}$, and $17 \%$ of patients receiving placebo $(p<0.001$ for both comparisons with placebo) [48]. At week 24 in FUTURE 2, which had a mixed population of TNF-naive and TNF-experienced patients, ACR 20 was achieved by $54 \%$ of patients receiving secukinumab $300 \mathrm{mg}(p<0.0001), 51 \%$ receiving secukinumab $150 \mathrm{mg}(p<0.0001), 29 \%$ receiving secukinumab $75 \mathrm{mg}(p=0.0399)$, and $15 \%$ of patients receiving placebo [46]. These improvements were sustained through 52 weeks of treatment $[46,48]$.

In the phase 3 SPIRIT-P1 trial of a TNF-naive population, significantly more patients achieved ACR20 with ixekizumab $80 \mathrm{mg}$ once every 2 weeks $(62 \%)$ and ixekizumab $80 \mathrm{mg}$ once every 4 weeks $(58 \%)$ than with placebo (30\%; both $p \leq 0.001$ ) [53]. A clinical trial of ixekizumab in biologic-experienced patients with active PsA is ongoing (NCT02349295).

\section{Ankylosing spondylitis}

Secukinumab also recently received FDA approval for the treatment of active AS. In a randomized, double-blind, phase 2 study, $59 \%$ of patients treated with secukinumab achieved rapid, meaningful clinical improvement in AS 
symptoms compared with $24 \%$ of patients who received placebo [54]. These improvements were maintained for up to 2 years in patients who continued in an open-label extension of this study [55]. The benefits of secukinumab in patients with AS were confirmed in the phase 3 MEASURE 1 and MEASURE 2 studies [47]. In these randomized controlled trials, patients received placebo, or IV or SC loading doses of secukinumab followed by SC maintenance dosing. In MEASURE 1 and MEASURE 2, respectively, at least $20 \%$ improvement in Assessment of SpondyloArthritis International Society (ASAS20) response rates at week 16 were $61 \%$ in both studies in the secukinumab $150 \mathrm{mg}$ group, $60 \%$ and $41 \%$ in the secukinumab $75 \mathrm{mg}$ group, and $29 \%$ and $28 \%$ for patients who received placebo [47]. Improvement in signs and symptoms of AS occurred rapidly with secukinumab and were sustained over time. Secukinumab was also associated with improvements in physical functioning and healthrelated quality of life compared with placebo [47].

Studies of ixekizumab in biologic treatment-naive (COAST-V) and treatment-experienced (COAST-W) patients with AS are ongoing (NCT02696785 and NCT02696798).

\section{Rheumatoid arthritis}

As suggested by basic research studies characterizing the different roles of IL-17A in RA and SpA [38], results from clinical studies of IL-17A inhibitors in RA indicate that these agents may have limited therapeutic efficacy in this patient population [56, 57]. In separate phase 2 studies of secukinumab and ixekizumab in patients with RA, ACR20 response rates differed across the dose ranges studied, without a consistent dose-response relationship [56, 57]. In a 16-week phase 2 study of secukinumab, ACR20 response rates ranged from 36\% to 54\% in the active-treatment arms, compared with $34 \%$ with placebo [56]. In a second 52-week phase 2 study of secukinumab, ACR20 response rates were not significantly different between secukinumab and placebo (42.9\% vs $40.9 \%$ ), but significant improvements were observed in the secukinumab arm based on 28-joint Disease Activity Score (DAS28), global assessments of disease activity, pain assessments, and high-sensitivity $\mathrm{C}$-reactive protein levels [58].

Among biologic treatment-naive patients in a phase 2 study of ixekizumab, ACR20 response rates ranged from $43 \%$ to $70 \%$, compared with $35 \%$ for placebo. In this study, ACR20 response rates were significantly higher with ixekizumab $80 \mathrm{mg}$ and $180 \mathrm{mg}$ compared with placebo for patients with prior inadequate response to TNF- $\alpha$ inhibitors [57]. Patients in this study were eligible to enter a 48-week open-label extension. Patients in the extension who experienced clinical improvements during the initial 16-week study generally maintained these improvements through week 64 [59].

Based on findings from these phase 2 studies, it cannot be ruled out that a subset of patients with RA may experience clinical benefits from treatment with IL-17A inhibitors. However, a recent study investigating the relationship between genetic biomarkers and secukinumab treatment response in patients with RA found that the human leukocyte antigen (HLA)-DRB1*04 and HLA-DRB1* shared epitope allelic groups were not predictive of treatment response [60].

\section{Safety profiles of secukinumab and ixekizumab}

IL-17A inhibitors have been shown to have good overall safety profiles [61]. In psoriasis clinical trials, secukinumab's side-effect profile was similar to that of the TNF- $\alpha$ inhibitor etanercept and the IL-12/IL-23 antagonist ustekinumab, with no safety signals indicating an increased risk for serious adverse events of interest, including malignancy, infection, or induction of autoimmune diseases $[44,49]$. In placebo-controlled studies of secukinumab in PsA and AS, the incidence and types of adverse events were similar between secukinumab and placebo, with a small increased risk for infections, including candidiasis [46-48]. Similarly, in the UNCOVER-2 and UNCOVER3 psoriasis clinical studies, rates of serious adverse events were low and similar with ixekizumab and etanercept, and a small number of Candida infections were reported [45].

\section{Management of comorbidities and extra-articular mani- festations of SpA}

It has been hypothesized, based on findings from recent research, that IL-17A inhibition may have beneficial effects on some of the common comorbidities observed in patients with SpA, as well as extra-articular symptoms of the disease, including uveitis and psoriasis [62]. Based on available data, Golden and colleagues [63] have speculated that the inflammation associated with increased levels of Th17 cells and their associated cytokines may initiate or worsen comorbidities, including atherosclerosis and metabolic syndrome; thus, it is logical to hypothesize that SpA treatments that modulate inflammatory responses in the Th17 pathway could have added benefits related to improvements in comorbidities.

In experiments performed by Barry and colleagues, prolonged elevations in IL-17RA, IL-17A, and IL-17F levels following myocardial ischemia/reperfusion injury in rats contributed to permanent cardiac damage [64]. In vivo experiments also showed that IL-17 neutralization reduced necrotic and apoptotic myocyte death, suggesting beneficial effects following human myocardial infarction [64]. 
Preclinical studies have linked increased IL-17 production with development of hypertension and endothelial dysfunction through promotion of oxidative stress in the kidneys and vasculature $[65,66]$. These findings are supported by results from a clinical study that showed serum IL-17 levels were significantly higher in patients with prehypertension compared with normotensive controls [67]. Additionally, Hautefort and colleagues [68] observed that monocyte-derived dendritic cells in patients with idiopathic pulmonary arterial hypertension induced greater activation and proliferation of $\mathrm{CD} 4^{+}$-derived Th17 cells, resulting in higher levels of IL-17 compared with controls.

In a large-scale, case-controlled, genetic screening study in patients with coronary artery disease (CAD), Zhang and colleagues [69] found a significant association between specific IL17A single nucleotide polymorphisms (SNPs) and risk of CAD and acute myocardial infarction in a Chinese Han population. Similarly, Vargas-Alarcón and colleagues [70] found associations between two IL17A haplotypes and development of premature CAD in a Mexican population. In the group that developed premature CAD, polymorphisms were also associated with increased risks for central obesity, increased visceral abdominal fat, and metabolic syndrome. Interestingly, such increased risks for obesity may contribute to disease pathogenesis in SpA because activated white adipose tissue stimulates production of IL-17 and other proinflammatory cytokines [71].

In a randomized, placebo-controlled, phase $2 \mathrm{a}$ trial of patients with moderate-to-severe Crohn's disease, IL17A inhibition with secukinumab did not meet its primary endpoint, and worsening of Crohn's disease was experienced by some patients [72]. However, in mechanistic studies, mixed findings have been reported for the role of IL-17 in the gut with both protective and proinflammatory effects observed [73] and additional research is required to fully understand the role of IL-17 in the gut. Although Crohn's disease has been reported in patients with AS treated with IL-17 inhibitors, a small number of individuals were affected (incidence rate of 0.7 cases per 100 patient-years in pooled secukinumabgroup data from MEASURE 1 and MEASURE 2) [47]. Furthermore, in large, pooled studies of patients with psoriasis treated with IL-17 inhibitors, IBD was reported infrequently (incidence rate of 0.33 cases per 100 patient-years with secukinumab and incidence rate of 2.9 cases per 1000 patient-years with ixekizumab) [74, 75]. The risk of IBD with IL-17 inhibition is minimal.

\section{Conclusions}

In summary, there is ample evidence supporting the central role of IL-17A-secreting cells in inflammation, bone resorption/remodeling, and cartilage damage associated with SpA, and there are strong mechanistic rationales for targeting this pathway in SpA disease management. Findings from clinical studies support these rationales and indicate that biologic IL-17A inhibitors may provide effective and well-tolerated alternatives to other approved treatments for the management of SpA.

\section{Abbreviations \\ ACR: American College of Rheumatology; AS: Ankylosing spondylitis; ASAS: Assessment of SpondyloArthritis International Society; CAD: Coronary artery disease; CIA: Collagen-induced arthritis; DAS28: 28-joint Disease Activity Score; FDA: Food and Drug Administration; HLA: Human leukocyte antigen; IBD: Inflammatory bowel disease; IFN: Interferon; IL: Interleukin; IL- 17RA: Interleukin-17 receptor A; IL-17RC: Interleukin-17 receptor C; \\ IV: Intravenous; MMP: Matrix metalloproteinase; NHANES: National Health and Nutrition Examination Survey; PASI: Psoriasis Area and Severity Index; \\ PsA: Psoriatic arthritis; RA: Rheumatoid arthritis; RANKL: Receptor activator of nuclear factor-KB ligand; SC: Subcutaneous; SNP: Single nucleotide polymorphism; SpA: Spondyloarthritis; TGF: Transforming growth factor; Th: T-helper; TNF: Tumor necrosis factor}

\section{Acknowledgments}

The authors were fully responsible for all content and editorial decisions and received no financial support or other form of compensation related to the development of this manuscript.

\section{Funding}

Technical assistance with editing and styling of the manuscript for submission was provided by Oxford PharmaGenesis Inc., and was funded by Novartis Pharmaceuticals Corporation.

\section{Availability of data and materials}

Not applicable.

\section{Authors' contributions}

SPR conceived of the concept for this review, and participated in its design and coordination, and drafted and reviewed the content of the manuscript. SKR conceived of the concept for this review, and participated in its design and coordination, and drafted and reviewed the content of the manuscript. Both authors read and approved the final manuscript.

\section{Competing interests}

The authors declare that they have no competing interests.

\section{Consent for publication}

Not applicable.

Ethics approval and consent to participate Not applicable.

Published online: 08 March 2017

\section{References}

1. 2014 ACR/SAA/SPARTAN recommendations for the management of axial spondyloarthritis, including ankylosing spondylitis, and children with the enthesitis-related arthritis form of juvenile idiopathic arthritis. Project plan. http://www.rheumatology.org/Portals/0/Files/ Axial\%20SpA\%20Project\%20Plan.pdf. Accessed 30 Aug 2016.

2. Raychaudhuri SK, Saxena A, Raychaudhuri SP. Role of IL-17 in the pathogenesis of psoriatic arthritis and axial spondyloarthritis. Clin Rheumatol. 2015;34:1019-23.

3. Singh AK, Misra R, Aggarwal A. Th-17 associated cytokines in patients with reactive arthritis/undifferentiated spondyloarthropathy. Clin Rheumatol. 2011;30:771-6.

4. Wendling D. Treating to target in axial spondyloarthritis: defining the target and the arrow. Expert Rev Clin Immunol. 2015;11:691-3.

5. Stolwijk C, Boonen A, van Tubergen A, Reveille JD. Epidemiology of spondyloarthritis. Rheum Dis Clin North Am. 2012;38:441-76. 
6. Reveille JD, Witter JP, Weisman MH. Prevalence of axial spondylarthritis in the United States: estimates from a cross-sectional survey. Arthritis Care Res (Hoboken). 2012;64:905-10.

7. Mitra A, Raychaudhuri SK, Raychaudhuri SP. Functional role of IL-22 in psoriatic arthritis. Arthritis Res Ther. 2012;14:R65.

8. Lubberts E. The IL-23-IL-17 axis in inflammatory arthritis. Nat Rev Rheumatol. 2015;11:415-29.

9. Sherlock JP, Joyce-Shaikh B, Turner SP, Chao CC, Sathe M, Grein J, et al. IL-23 induces spondyloarthropathy by acting on $\mathrm{ROR}-\gamma \mathrm{t}^{+} \mathrm{CD}^{+} \mathrm{CD}^{-} \mathrm{CD} 8$ entheseal resident T cells. Nat Med. 2012;18:1069-76.

10. Cai Y, Shen X, Ding C, Qi C, Li K, Li X, et al. Pivotal role of dermal IL-17producing $\gamma \delta$ T cells in skin inflammation. Immunity. 2011;35:596-610.

11. Numasaki M, Fukushi J, Ono M, Narula SK, Zavodny PJ, Kudo T, et al. Interleukin17 promotes angiogenesis and tumor growth. Blood. 2003;101:2620-7.

12. Raychaudhuri SP. Role of IL-17 in psoriasis and psoriatic arthritis. Clin Rev Allergy Immunol. 2013;44:183-93.

13. Yamamoto M, Nakajima K, Takaishi M, Kitaba S, Magata Y, Kataoka S, et al. Psoriatic inflammation facilitates the onset of arthritis in a mouse model. $J$ Invest Dermatol. 2015;135:445-53.

14. Rossini M, Viapiana O, Adami S, Idolazzi L, Fracassi E, Gatti D. Focal bone involvement in inflammatory arthritis: the role of IL 17. Rheumatol Int. 2016;36:469-82

15. Smith JA, Colbert RA. The interleukin-23/interleukin-17 axis in spondyloarthritis pathogenesis: Th17 and beyond. Arthritis Rheumatol. 2014;66:231-41.

16. Wendling D, Guillot X, Prati C. The IL-23/Th 17 pathway in spondyloarthritis: the royal road? Joint Bone Spine. 2015;82:1-4.

17. Conti HR, Gaffen SL. IL-17-mediated immunity to the opportunistic fungal pathogen candida albicans. J Immunol. 2015;195:780-8

18. Gaffen SL. Structure and signalling in the IL-17 receptor family. Nat Rev Immunol. 2009;9:556-67.

19. Lubberts E, Joosten LA, Oppers B, van den Bersselaar L, Coenen-de Roo CJ, Kolls JK, et al. IL-1-independent role of IL-17 in synovial inflammation and joint destruction during collagen-induced arthritis. J Immunol. 2001;167:1004-13.

20. Lubberts $E$, van den Bersselaar $L$, Oppers-Walgreen B, Schwarzenberger $P$, Coenen-de Roo CJ, Kolls JK, et al. IL-17 promotes bone erosion in murine collagen-induced arthritis through loss of the receptor activator of NF-KB ligand/osteoprotegerin balance. J Immunol. 2003;170:2655-62.

21. Benham H, Rehaume LM, Hasnain SZ, Velasco J, Baillet AC, Ruutu M, et al. Interleukin-23 mediates the intestinal response to microbial $\beta$-1,3-glucan and the development of spondyloarthritis pathology in SKG mice. Arthritis Rheumatol. 2014;66:1755-67.

22. Duerr RH, Taylor KD, Brant SR, Rioux JD, Silverberg MS, Daly MJ, et al. A genome-wide association study identifies IL23R as an inflammatory bowel disease gene. Science. 2006;314:1461-3.

23. Cargill M, Schrodi SJ, Chang M, Garcia VE, Brandon R, Callis KP, et al. A largescale genetic association study confirms IL $12 B$ and leads to the identification of IL23R as psoriasis-risk genes. Am J Hum Genet. 2007:80:273-90.

24. Wellcome Trust Case Control Consortium, Australo-Anglo-American Spondylitis Consortium (TASC), Burton PR, Clayton DG, Cardon LR, Craddock $\mathrm{N}$, et al. Association scan of 14,500 nonsynonymous SNPs in four diseases identifies autoimmunity variants. Nat Genet. 2007;39:1329-37.

25. Reinhardt A, Yevsa T, Worbs T, Lienenklaus S, Sandrock I, Oberdörfer L, et al. Interleukin-23-dependent $\gamma / \delta T$ cells produce interleukin-17 and accumulate in the enthesis, aortic valve, and ciliary body in mice. Arthritis Rheumatol. 2016:68:2476-86

26. Lubberts E, Koenders MI, Oppers-Walgreen B, van den Bersselaar L, Coenende Roo CJ, Joosten LA, et al. Treatment with a neutralizing anti-murine interleukin-17 antibody after the onset of collagen-induced arthritis reduces joint inflammation, cartilage destruction, and bone erosion. Arthritis Rheum. 2004:50:650-9.

27. Adamopoulos IE, Suzuki E, Chao CC, Gorman D, Adda S, Maverakis E, et al. IL-17A gene transfer induces bone loss and epidermal hyperplasia associated with psoriatic arthritis. Ann Rheum Dis. 2015;74:1284-92.

28. Jandus C, Bioley G, Rivals JP, Dudler J, Speiser D, Romero P. Increased numbers of circulating polyfunctional Th17 memory cells in patients with seronegative spondylarthritides. Arthritis Rheum. 2008:58:2307-17.

29. Singh R, Aggarwal A, Misra R. Th1/Th17 cytokine profiles in patients with reactive arthritis/undifferentiated spondyloarthropathy. J Rheumatol. 2007;34:2285-90.

30. Xueyi L, Lina C, Zhenbiao W, Qing H, Qiang L, Zhu P. Levels of circulating Th17 cells and regulatory T cells in ankylosing spondylitis patients with an inadequate response to anti-TNF-a therapy. J Clin Immunol. 2013;33:151-61.
31. Londono J, Romero-Sanchez MC, Torres VG, Bautista WA, Fernandez DJ, de Avila QA, et al. The association between serum levels of potential biomarkers with the presence of factors related to the clinical activity and poor prognosis in spondyloarthritis. Rev Bras Reumatol. 2012;52:529-44.

32. Ciccia F, Guggino G, Ferrante A, Raimondo S, Bignone R, Rodolico V, et al. Interleukin-9 overexpression and Th9 polarization characterize the inflamed gut, the synovial tissue, and the peripheral blood of patients with psoriatic arthritis. Arthritis Rheumatol. 2016;68:1922-31.

33. Raychaudhuri SP, Raychaudhuri SK, Genovese MC. IL-17 receptor and its functional significance in psoriatic arthritis. Mol Cell Biochem. 2012;359:419-29.

34. Jansen DT, Hameetman M, van Bergen J, Huizinga TW, van der Heijde D, Toes RE, et al. IL-17-producing CD4 ${ }^{+} \mathrm{T}$ cells are increased in early, active axial spondyloarthritis including patients without imaging abnormalities. Rheumatology (Oxford). 2015;54:728-35.

35. Kenna TJ, Davidson SI, Duan R, Bradbury LA, McFarlane J, Smith M, et al. Enrichment of circulating interleukin-17-secreting interleukin-23 receptorpositive $\gamma / \delta$ T cells in patients with active ankylosing spondylitis. Arthritis Rheum. 2012;64:1420-9.

36. Noordenbos T, Yeremenko N, Gofita I, van de Sande M, Tak PP, Caňete JD, et al. Interleukin-17-positive mast cells contribute to synovial inflammation in spondylarthritis. Arthritis Rheum. 2012:64:99-109.

37. Lories RJ, Baeten DL. Differences in pathophysiology between rheumatoid arthritis and ankylosing spondylitis. Clin Exp Rheumatol. 2009;27:S10-4.

38. Menon B, Gullick NJ, Walter GJ, Rajasekhar M, Garrood T, Evans HG, et al. Interleukin-17 + CD8+ T cells are enriched in the joints of patients with psoriatic arthritis and correlate with disease activity and joint damage progression. Arthritis Rheumatol. 2014;66:1272-81.

39. Van den Bosch F, Deodhar A. Treatment of spondyloarthritis beyond TNFalpha blockade. Best Pract Res Clin Rheumatol. 2014;28:819-27.

40. Colbert RA, Ward MM. 17 and 23: prime numbers for ankylosing spondylitis? Lancet. 2013;382:1682-3.

41. Toussirot E. Biologics in spondyloarthritis: TNFa inhibitors and other agents. Immunotherapy. 2015;7:669-81.

42. Lories RJ, de Vlam K. Tumour necrosis factor inhibitors in the treatment of psoriatic arthritis: a view on effectiveness, clinical practice and toxicity. Expert Opin Biol Ther. 2014:14:1825-36.

43. Rohekar S, Chan J, Tse SM, Haroon N, Chandran V, Bessette L, et al. 2014 Update of the Canadian Rheumatology Association/Spondyloarthritis Research Consortium of Canada treatment recommendations for the management of spondyloarthritis. Part II: specific management recommendations. J Rheumatol. 2015;42:665-81.

44. Langley RG, Elewski BE, Lebwohl M, Reich K, Griffiths CE, Papp K, et al. Secukinumab in plaque psoriasis_results of two phase 3 trials. N Engl J Med. 2014;371:326-38.

45. Griffiths CE, Reich K, Lebwohl M, van de Kerkhof P, Paul C, Menter A, et al. Comparison of ixekizumab with etanercept or placebo in moderate-tosevere psoriasis (UNCOVER-2 and UNCOVER-3): results from two phase 3 randomised trials. Lancet. 2015;386:541-51.

46. Mclnnes IB, Mease PJ, Kirkham B, Kavanaugh A, Ritchlin CT, Rahman P, et al. Secukinumab, a human anti-interleukin-17A monoclonal antibody, in patients with psoriatic arthritis (FUTURE 2): a randomised, double-blind, placebo-controlled, phase 3 trial. Lancet. 2015;386:1137-46.

47. Baeten D, Sieper J, Braun J, Baraliakos X, Dougados M, Emery P, et al. Secukinumab, an interleukin-17A inhibitor, in ankylosing spondylitis. N Engl J Med. 2015:373:2534-48.

48. Mease PJ, Mclnnes IB, Kirkham B, Kavanaugh A, Rahman P, van der Heijde D, et al. Secukinumab inhibition of interleukin-17A in patients with psoriatic arthritis. N Engl J Med. 2015;373:1329-39.

49. Thaci D, Blauvelt A, Reich K, Tsai TF, Vanaclocha F, Kingo K, et al. Secukinumab is superior to ustekinumab in clearing skin of subjects with moderate to severe plaque psoriasis: CLEAR, a randomized controlled trial. J Am Acad Dermatol. 2015:73:400-9.

50. Papp KA, Reich K, Paul C, Blauvelt A, Baran W, Bolduc C, et al. A prospective phase III, randomized, double-blind, placebo-controlled study of brodalumab in patients with moderate-to-severe plaque psoriasis. $\mathrm{Br} J$ Dermatol. 2016;175:273-86.

51. Lebwohl M, Strober B, Menter A, Gordon K, Weglowska J, Puig L, et al. Phase 3 studies comparing brodalumab with ustekinumab in psoriasis. N Engl J Med. 2015;373:1318-28.

52. Danesh MJ, Kimball AB. Brodalumab and suicidal ideation in the context of a recent economic crisis in the United States. J Am Acad Dermatol. 2016;74:190-2. 
53. Mease PJ, van der Heijde D, Ritchlin CT, Okada M, Cuchacovich RS, Shuler $\mathrm{CL}$, et al. Ixekizumab, an interleukin-17A specific monoclonal antibody, for the treatment of biologic-naive patients with active psoriatic arthritis: results from the 24-week randomised, double-blind, placebo-controlled and active (adalimumab)-controlled period of the phase III trial SPIRIT-P1. Ann Rheum Dis. 2016;76:79-87.

54. Baeten D, Baraliakos X, Braun J, Sieper J, Emery P, van der Heijde D, et al. Anti-interleukin-17A monoclonal antibody secukinumab in treatment of ankylosing spondylitis: a randomised, double-blind, placebo-controlled trial. Lancet. 2013;382:1705-13.

55. Baraliakos X, Borah B, Braun J, Baeten D, Laurent D, Sieper J, et al. Longterm effects of secukinumab on MRI findings in relation to clinical efficacy in subjects with active ankylosing spondylitis: an observational study. Ann Rheum Dis. 2016;75:408-12.

56. Genovese MC, Durez P, Richards HB, Supronik J, Dokoupilova E, Mazurov V, et al. Efficacy and safety of secukinumab in patients with rheumatoid arthritis: a phase II, dose-finding, double-blind, randomised, placebo controlled study. Ann Rheum Dis. 2013;72:863-9.

57. Genovese MC, Greenwald M, Cho CS, Berman A, Jin L, Cameron GS, et al. A phase II randomized study of subcutaneous ixekizumab, an anti-interleukin17 monoclonal antibody, in rheumatoid arthritis patients who were naive to biologic agents or had an inadequate response to tumor necrosis factor inhibitors. Arthritis Rheumatol. 2014;66:1693-704.

58. Tlustochowicz W, Rahman P, Seriolo B, Krammer G, Porter B, Widmer A, et al. Efficacy and safety of subcutaneous and intravenous loading dose regimens of secukinumab in patients with active rheumatoid arthritis: results from a randomized phase II study. J Rheumatol. 2016;43:495-503.

59. Genovese MC, Braun DK, Erickson JS, Berclaz PY, Banerjee S, Heffernan MP, et al. Safety and efficacy of open-label subcutaneous ixekizumab treatment for 48 weeks in a phase II study in biologic-naive and TNF-IR patients with rheumatoid arthritis. J Rheumatol. 2016;43:289-97.

60. Burmester GR, Durez P, Shestakova G, Genovese MC, Schulze-Koops H, Li Y, et al. Association of HLA-DRB1 alleles with clinical responses to the antiinterleukin-17A monoclonal antibody secukinumab in active rheumatoid arthritis. Rheumatology (Oxford). 2016;55:49-55.

61. Xiong HZ, Gu JY, He ZG, Chen WJ, Zhang X, Wang JY, et al. Efficacy and safety of secukinumab in the treatment of moderate to severe plaque psoriasis: a metaanalysis of randomized controlled trials. Int J Clin Exp Med. 2015;8:3156-72.

62. Letko E, Yeh S, Foster CS, Pleyer U, Brigell M, Grosskreutz CL, et al. Efficacy and safety of intravenous secukinumab in noninfectious uveitis requiring steroidsparing immunosuppressive therapy. Ophthalmology. 2015;122:939-48.

63. Golden JB, McCormick TS, Ward NL. IL-17 in psoriasis: implications for therapy and cardiovascular co-morbidities. Cytokine. 2013;62:195-201.

64. Barry SP, Ounzain S, McCormick J, Scarabelli TM, Chen-Scarabelli C, Saravolatz LI, et al. Enhanced IL-17 signalling following myocardial ischaemia/reperfusion injury. Int J Cardiol. 2013;163:326-34.

65. Trott DW, Harrison DG. The immune system in hypertension. Adv Physiol Educ. 2014;38:20-4.

66. Harrison DG. The immune system in hypertension. Trans Am Clin Climatol Assoc. 2014;125:130-8. discussion 138-40.

67. Yao W, Sun Y, Wang X, Niu K. Elevated serum level of interleukin 17 in a population with prehypertension. J Clin Hypertens (Greenwich). 2015;17:770-4.

68. Hautefort A, Girerd B, Montani D, Cohen-Kaminsky S, Price L, Lambrecht BN, et al. T-helper 17 cell polarization in pulmonary arterial hypertension. Chest. 2015;147:1610-20

69. Zhang X, Pei F, Zhang M, Yan C, Huang M, Wang T, et al. Interleukin-17A gene variants and risk of coronary artery disease: a large angiography-based study. Clin Chim Acta. 2011;412:327-31.

70. Vargas-Alarcón G, Angeles-Martínez J, Villarreal-Molina T, Alvarez-León E, Posadas-Sánchez R, Cardoso-Saldaña G, et al. Interleukin-17A gene haplotypes are associated with risk of premature coronary artery disease in Mexican patients from the Genetics of Atherosclerotic Disease (GEA) study. PLoS One. 2015;10:e0114943

71. Raychaudhuri SP. Comorbidities of psoriatic arthritis-metabolic syndrome and prevention: a report from the GRAPPA 2010 annual meeting. J Rheumatol. 2012;39:437-40.

72. Hueber W, Sands BE, Lewitzky S, Vandemeulebroecke M, Reinisch W, Higgins PD, et al. Secukinumab, a human anti-IL-17A monoclonal antibody, for moderate to severe Crohn's disease: unexpected results of a randomised, double-blind placebo-controlled trial. Gut. 2012;61:1693-700.
73. Xu XR, Liu CQ, Feng BS, Liu ZJ. Dysregulation of mucosal immune response in pathogenesis of inflammatory bowel disease. World J Gastroenterol. 2014;20:3255-64.

74. van de Kerkhof PC, Griffiths CE, Reich K, Leonardi CL, Blauvelt A, Tsai TF, et al. Secukinumab long-term safety experience: a pooled analysis of 10 phase II and III clinical studies in patients with moderate to severe plaque psoriasis. J Am Acad Dermatol. 2016;75:83-98. e4.

75. Reich K, Leonardi C, Langley RG, Warren RB, Bachelez H, Romiti R, et al. Inflammatory bowel disease among patients with psoriasis treated with ixekizumab: a presentation of adjudicated data from an integrated database of 7 randomized controlled and uncontrolled trials. J Am Acad Dermatol. 2016. doi: 10.1016/j.jaad.2016.10.027.

76. Kim JS, Jordan MS. Diversity of IL-17-producing T lymphocytes. Cell Mol Life Sci. 2013;70:2271-90

77. Spits H, Artis D, Colonna M, Diefenbach A, Di Santo JP, Eberl G, et al. Innate lymphoid cells - a proposal for uniform nomenclature. Nat Rev Immunol. 2013;13:145-9.

78. Kugyelka R, Kohl Z, Olasz K, Mikecz K, Rauch TA, Glant T, et al. Enigma of IL-17 and Th17 cells in rheumatoid arthritis and in autoimmune animal models of arthritis. Mediators Inflamm. 2016;2016:6145810.

79. Lee JS, Tato CM, Joyce-Shaikh B, Gulen MF, Cayatte C, Chen Y, et al. Interleukin-23-independent IL-17 production regulates intestinal epithelial permeability. Immunity. 2015;43:727-38.

80. Martin B, Hirota K, Cua DJ, Stockinger B, Veldhoen M. Interleukin-17producing gammadelta $T$ cells selectively expand in response to pathogen products and environmental signals. Immunity. 2009;31:321-30. 